\title{
Clinical Reasoning: An adolescent girl presenting with worsening vertigo, headache, and ataxia
}

Elizabeth Brigham, MD, Chichun Sun, DO, Richard Bronnenkant, MD, Ashutosh Kumar, MD, and Kristin Disori, MD, MPH

Neurology ${ }^{\circledR}$ 2020;95:e1760-e1763. doi:10.1212/WNL.0000000000010233
Correspondence

Dr. Brigham

elizabethmbrigham@

gmail.com

\section{Section 1}

A 16-year-old girl presents to the Emergency Department with 1 week of vertigo. Her vertiginous symptoms began acutely and were described as a sensation of the room spinning. She subsequently developed a headache, nausea, and difficulty walking. On day 2 of illness, her primary care physician prescribed a 5-day course of prednisone and meclizine twice daily. Her symptoms did not improve following the steroid course, prompting an outpatient MRI of the brain. This study identified sinus disease, but no intracranial abnormality. Her meclizine dose was increased, and she was started on cefdinir for treatment of sinusitis. However, her symptoms continued to worsen. At the time of presentation to our service, she was unable to stand due to the vertigo. She complained of headache and nausea and was found to have nystagmus, ataxia, and dysmetria on examination. The patient had experienced one episode of headache approximately a year prior to presentation but was otherwise healthy. Her family history was significant for a grandmother with multiple sclerosis (MS) and a brother with Factor V Leiden and prothrombin gene mutation.

\section{Questions for consideration:}

1. What are the differential diagnoses?

2. What additional tests would you consider to delineate the cause of her vertigo and headache?

GO TO SECTION 2 


\section{Section 2}

The differential diagnosis was broad and included infection (e.g., meningitis), autoimmune/paraneoplastic encephalitis, inflammatory etiologies (e.g., MS and neuromyelitis optica), toxic/metabolic etiologies (e.g., ingestion, vitamin $B_{1}$ and $B_{12}$ deficiency), and vascular abnormalities (e.g., cerebral venous sinus thrombosis). Magnetic resonance angiography and magnetic resonance venography of the head and neck were within normal limits except for the previously noted maxillary sinusitis. Venous sinus thrombosis and arterial dissection were ruled out by imaging. A lumbar puncture revealed a mild CSF pleocytosis with lymphocytic predominance (11 white blood cells $/ \mu \mathrm{L}, 0$ red blood cells $/ \mu \mathrm{L}, 0 \%$ neutrophils, $78 \%$ lymphocytes, $2 \%$ monocytes, $20 \%$ unidentified degenerated cells). The remainder of her CSF studies including protein, glucose, culture, and cytology were normal.

While other CSF studies were pending, ophthalmology was consulted to evaluate for optic neuritis due to the concern for possible CNS inflammatory disorders. On examination, no optic neuritis was identified, but the abnormal eye movements initially thought to be consistent with nystagmus were recharacterized as opsoclonus. The patient's mother described new jerking movements that were occurring during the patient's sleep, raising concern for myoclonus and opsoclonus-myoclonus syndrome (OMS). A routine EEG did not demonstrate any epileptiform activity. To evaluate for a paraneoplastic etiology for her OMS, urine vanillylmandelic acid and homovanillic acid were sent to rule out neuroblastoma. Although it was on the differential, neuroblastoma would have been rare within her age group. An MRI of the
Figure $1 \mathrm{MRI}$ pelvis identifying left ovarian teratoma

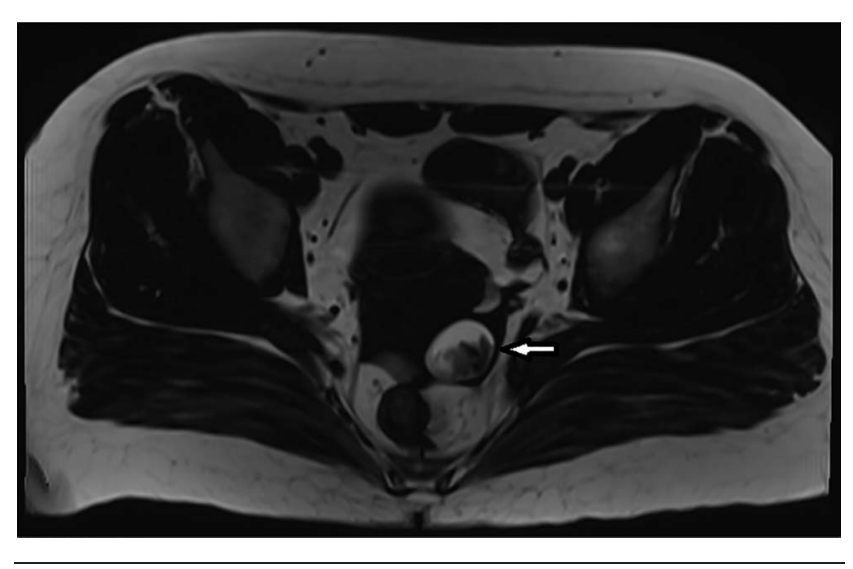

chest, abdomen, and pelvis was also performed to further assess for a paraneoplastic cause for her symptoms. Given the differentials under consideration, pan-imaging (chest, abdomen, and pelvis) was selected over more focused imaging of the abdomen. Despite the cost and length of the study, MRI was chosen over CT to limit radiation exposure to an otherwise healthy patient. ${ }^{1}$ With a body mass index of 33 , ultrasound of the abdomen and pelvis may have resulted in suboptimal visualization of relevant structures. The pelvic MRI identified a left ovarian teratoma measuring $3.5 \mathrm{~cm}$ in diameter (figure 1).

\section{Question for consideration:}

1. What are the next steps in managing the patient's symptoms?

\section{GO TO SECTION 3}




\section{Section 3}

The patient underwent a left ovarian cystectomy during her hospitalization. The final surgical pathology identified the mass as a mature ovarian cystic teratoma. Paraneoplastic, aquaporin-4 (AQP-4) receptor antibody, and MS panels sent from the patient's CSF subsequently proved negative, though she did have elevated serum GAD65 antibody levels (0.10 $\mathrm{nmol} / \mathrm{L}$, normal: $\leq 0.02 \mathrm{nmol} / \mathrm{L}$ ). The patient's vertigo and myoclonus began to improve following the resection, though she spent 2 weeks at inpatient rehabilitation to address residual deficits.

Two weeks after discharge from the rehabilitation hospital, the patient again developed worsening opsoclonus and myoclonus along with behavioral changes. She was readmitted to the hospital, and repeat abdominal and pelvic imaging revealed recurrence of her ovarian teratoma (figure 2). She underwent left oophorectomy and completed a course of high-dose steroids. Her symptoms improved, and she was discharged to inpatient rehabilitation and ultimately to home. Her opsoclonus and myoclonus resolved completely after the second surgery, but she continued to have mild ataxia, slow speech, and behavioral issues at her 4-month follow-up visit with pediatric neurology. Her remaining symptoms resolved, except for very subtle ataxia, by the time of her 10-month follow-up evaluation.

\section{Discussion}

OMS, also known as opsoclonus-myoclonus ataxia, is a rare condition; the reported incidence in pediatric patients is between 0.18 cases per million in the United Kingdom and $0.27-0.40$ cases per million in Japan., ${ }^{2,3}$ Proposed diagnostic criteria require the presence of at least 3 of these 4 findings: (1) opsoclonus, (2) myoclonus, (3) behavioral changes and/or sleep disturbances, and (4) neuroblastoma. ${ }^{4}$ Our patient met the first 3 of these criteria. Features of this syndrome overlap with other etiologies of acute

Figure $2 \mathrm{MRI}$ pelvis identifying recurrent left ovarian teratoma

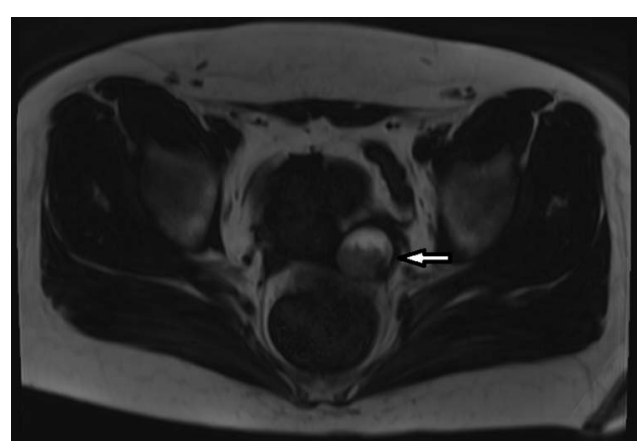

ataxia in children ${ }^{5}$ and can present a diagnostic challenge, especially when symptoms evolve over time. OMS can be caused by a variety of etiologies, most notably postinfectious or paraneoplastic syndromes. In children, it is associated with neuroblastoma in $50 \%$ of the cases. ${ }^{4}$ In adults, it is more often associated with small cell lung, breast, and ovarian cancers. ${ }^{6}$ Cases of OMS associated with ovarian teratomas have been reported in both adolescents and adults. ${ }^{7,8}$

The pathophysiology of OMS is thought to be autoimmune in nature. Though many patients do not have identified autoantibodies, those with gynecologic malignancies and OMS may test positive for ANNA-2 (Anti-Ri) antibodies. ${ }^{6}$ NMDA receptor antibody has also been found in some cases. ${ }^{9} \mathrm{Au}-$ toantibodies to glutamic acid decarboxylase (GAD) have been associated with cerebellar ataxia, stiff-person syndrome, and limbic encephalitis. ${ }^{6}$ Our patient had elevated anti-GAD65 in the serum, but not CSF, and it is unclear what role this played in her presentation.

The evidence for management of OMS is limited, yet the most consistent approach is immunotherapy and tumor resection. The immunotherapeutic approaches that have been used in children include corticosteroids, adrenocorticotropic hormone, IV immunoglobulin, plasma exchange, cyclophosphamide, and rituximab. ${ }^{4}$ Even though multiple immunotherapies have been utilized, there are no established guidelines to recommend one therapy over another. More research is needed in order to study the efficacy of each therapeutic option.

Our patient had demonstrated improvement following her initial tumor resection, but experienced symptom relapse with tumor recurrence. Further management involved both surgical and pharmacologic interventions (steroids), which led to a more rapid and sustained improvement in symptoms. This highlights the dual role of immunotherapy and tumor resection in OMS management. OMS may be monophasic or have a relapsing course. More severe symptomatology at the time of presentation is associated with recurrence. ${ }^{10}$ Long-term neurocognitive effects are seen in OMS. Though some patients may recover without residual deficits, ${ }^{8}$ motor abnormalities, cognitive delays, and speech difficulties may remain many years after the initial illness. At her 4-month follow-up, our patient, while significantly improved, was still experiencing mild ataxia, behavioral changes, and slowing of speech. At her 10-month follow-up visit, all of her symptoms had resolved except for very subtle ataxia.

Clinicians generally associate OMS with neuroblastoma in pediatric patients. Pediatricians should expand their differential diagnosis to include ovarian teratoma, particularly in adolescent patients. Paraneoplastic OMS is a rare but potentially debilitating syndrome. Early recognition is important, despite potential diagnostic challenges. Additional 
studies are needed to establish recommendations for immunotherapeutic management.

\section{Study funding}

No targeted funding reported.

\section{Disclosure}

The authors report no disclosures relevant to the manuscript. Go to Neurology.org/N for full disclosures.

\begin{tabular}{lll} 
Appendix Authors \\
\hline Name & Location & Contribution \\
\hline $\begin{array}{l}\text { Elizabeth } \\
\text { Brigham, MD }\end{array}$ & $\begin{array}{l}\text { Penn State Milton S. } \\
\text { Hershey Medical } \\
\text { Center }\end{array}$ & $\begin{array}{l}\text { Corresponding author, } \\
\text { participated in drafting and } \\
\text { editing of manuscript }\end{array}$ \\
\hline $\begin{array}{l}\text { Chichun Sun, } \\
\text { DO }\end{array}$ & $\begin{array}{l}\text { Penn State Milton S. } \\
\text { Hershey Medical } \\
\text { Center }\end{array}$ & $\begin{array}{l}\text { Participated in drafting and } \\
\text { editing of manuscript }\end{array}$ \\
\hline $\begin{array}{l}\text { Richard } \\
\text { Bronnenkant, } \\
\text { MD }\end{array}$ & $\begin{array}{l}\text { Penn State Milton S. } \\
\text { Hershey Medical }\end{array}$ & $\begin{array}{l}\text { Participated in drafting and } \\
\text { editing of manuscript }\end{array}$ \\
\hline $\begin{array}{l}\text { Ashutosh } \\
\text { Kumar, MD }\end{array}$ & $\begin{array}{l}\text { Penn State Milton S. } \\
\text { Hershey Medical } \\
\text { Center }\end{array}$ & $\begin{array}{l}\text { Edited final manuscript, } \\
\text { provided guidance throughout } \\
\text { the submission process }\end{array}$ \\
\hline
\end{tabular}

Appendix (continued)

\begin{tabular}{lll}
\hline Name & Location & Contribution \\
\hline $\begin{array}{ll}\text { Kristin Disori, } \\
\text { MD }\end{array}$ & $\begin{array}{l}\text { Penn State Milton S. } \\
\text { Hershey Medical } \\
\text { Center }\end{array}$ & $\begin{array}{l}\text { Edited final manuscript, } \\
\text { provided guidance throughout } \\
\text { the submission process }\end{array}$ \\
\hline
\end{tabular}

\section{References}

1. Park C, Aljabban I, Fanburg-Smith JC, Grant C, Moore M. Pediatric whole body MRI detects causative ovarian teratoma in opsoclonus myoclonus syndrome. Radiol Case Rep 2020;15:204-209.

2. Pang K, de Sousa C, Lang B, Pike M. A prospective study of the presentation and management of dancing eye syndrome/opsoclonus-myoclonus syndrome in the United Kingdom. Eur J Paediatr Neurol 2010;14:156-161.

3. Hasegawa S, Matsushige T, Kajimoto M, et al. A nationwide survey of opsoclonusmyoclonus syndrome in Japanese children. Brain Dev 2015;37:656-660.

4. Matthay K, Blaes F, Hero B, et al. Opsoclonus myoclonus syndrome in neuroblastoma: a report from a workshop on the dancing eyes syndrome at the advances in neuroblastoma meeting in Genoa, Italy, 2004. Cancer Lett 2005;228:275-282.

5. Thakkar K, Maricich S, Alper G. Acute ataxia in childhood: 11-year experience at a major pediatric referral center. J Child Neurol 2016;31:1156-1160.

6. Dalmau J, Rosenfeld MR. Paraneoplastic syndromes of the CNS. Lancet Neurol 2008; 7:327-340.

7. Fitzpatrick AS, Gray OM, McConville J, McDonnell GV. Opsoclonus-myoclonus syndrome associated with benign ovarian teratoma. Neurology 2008;70:1292-1293.

8. Kanno K, Kin S, Hirose M, Suzuki S, Watanabe T, Fujimori K. Opsoclonus-ataxia syndrome associated with ovarian mature teratoma. J Obstet Gynaecol Res 2015;41: $1149-1153$

9. Klaas JP, Ahlskog JE, Pittock SJ, et al. Adult-onset opsoclonus-myoclonus syndrome. Arch Neurol 2012;69:1598-1607.

10. Brunklaus A, Pohl K, Zuberi S, de Sousa C. Outcome and prognostic features in opsoclonus-myoclonus syndrome from infancy to adult life. Pediatrics 2011;128: e388-e394. 


\section{Neurology}

\section{Clinical Reasoning: An adolescent girl presenting with worsening vertigo, headache, and ataxia \\ Elizabeth Brigham, Chichun Sun, Richard Bronnenkant, et al.}

Neurology 2020;95;e1760-e1763 Published Online before print July 8, 2020

DOI 10.1212/WNL.0000000000010233

\section{This information is current as of July 8, 2020}

\section{Updated Information \& Services}

References

Subspecialty Collections

Permissions \& Licensing

Reprints including high resolution figures, can be found at: http://n.neurology.org/content/95/12/e1760.full

This article cites 10 articles, 1 of which you can access for free at: http://n.neurology.org/content/95/12/e1760.full\#ref-list-1

This article, along with others on similar topics, appears in the following collection(s):

All Pediatric

http://n.neurology.org/cgi/collection/all_pediatric

Gait disorders/ataxia

http://n.neurology.org/cgi/collection/gait_disorders_ataxia

Myoclonus

http://n.neurology.org/cgi/collection/myoclonus

Paraneoplastic syndrome

http://n.neurology.org/cgi/collection/paraneoplastic_syndrome

Information about reproducing this article in parts (figures,tables) or in its entirety can be found online at:

http://www.neurology.org/about/about_the_journal\#permissions

Information about ordering reprints can be found online:

http://n.neurology.org/subscribers/advertise

Neurology ${ }^{\circledR}$ is the official journal of the American Academy of Neurology. Published continuously since 1951 , it is now a weekly with 48 issues per year. Copyright @ 2020 American Academy of Neurology. All rights reserved. Print ISSN: 0028-3878. Online ISSN: 1526-632X.

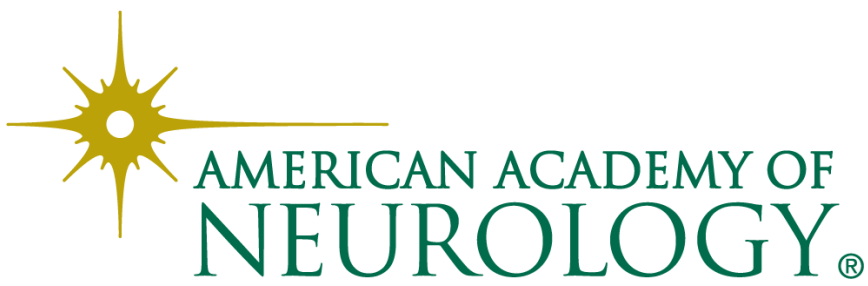

